\title{
NITROGEN MANAGEMENT
}

\section{Corn Root Effects on the Nitrogen-Supplying Capacity of a Conditioned Soil}

\author{
Jose E. Sanchez,* Eldor A. Paul, Thomas C. Willson, Jeffrey Smeenk, and Richard R. Harwood
}

\begin{abstract}
The design of sustainable $\mathbf{N}$ management strategies requires a better understanding of the processes influencing the ability of soils to supply $\mathbf{N}$ to a growing crop. Although commonly ignored, the release of $\mathbf{C}$ by plant roots may have a tremendous impact on soil organic matter turnover under certain soil conditions. The main objective of this study was to determine if living corn (Zea mays L.) roots would increase the $\mathbf{N}$-supplying capacity of a soil with an enhanced mineralizable $\mathbf{N}$ pool. A rotation of corn-corn-soybean [Glycine max (L.) Merr.]-wheat (Triticum aestivum $\mathbf{L}$.) in combination with cover crops and the application of composted manure were used to increase the mineralizable $\mathbf{N}$ pool. The $\mathbf{N}$-supplying capacity of bare soil and soils planted with corn and wheat was calculated, and changes in $\mathbf{N}$ and $C$ pool sizes were determined by laboratory incubations. Living corn roots increased the inorganic $\mathrm{N}$-supplying capacity of the conditioned soil by $>\mathbf{5 0} \%$. We suggest that this increase is caused by an increase in net $\mathrm{N}$ mineralization. This is supported by the considerable size reduction of the 70-d $\mathrm{N}$ pool in the soil planted with corn. No significant increase in the soil $\mathrm{N}$-supplying capacity was observed when wheat was planted, indicating the possibility that this effect may vary dramatically among plant species. The contribution of corn and wheat root rhizodeposition to the active $\mathbf{C}$ pool and as energy source to enhance microbial activity and organic matter turnover is discussed.
\end{abstract}

$\mathrm{N}$ ITROGEN MINERALIZATION, which is a microbiologically mediated process consisting of the transformation of organic $\mathrm{N}$ to $\mathrm{NH} 4$, is a major contributor to the amount of soil $\mathrm{N}$ available for plant uptake. Corn may derive up to $70 \%$ of its required $\mathrm{N}$ from the mineralization of soil N (Meisinger et al., 1985; Sanchez and Blackmer, 1988). The presence of plant roots has significant effects on the soil microbial population because conditions for microbial growth are especially favorable in the rhizosphere (Barber and Lynch, 1977; Newman, 1985; Foster, 1988; Bazin et al., 1990). For example, the soil microflora is heavily influenced by $\mathrm{C}$ sources derived from rhizodeposition (Curl and Harper, 1990). Rhizodeposits are easily decomposable substrates translocated from the aboveground parts of the plant to the roots and subsequently transferred into the surrounding soil as root exudates, mucilage, and sloughed cells and tissues (Qian et al., 1997). The role of rhizodeposits in the turnover of soil organic matter has been controversial for many years. A number of studies have reported

J.E. Sanchez, J. Smeenk, and R.R. Harwood, Dep. of Crop and Soil Sci., Michigan State Univ., East Lansing, MI 48824; E.A. Paul, Nat. Resour. Ecol. Lab., Colorado State Univ., Fort Collins, CO 80523; and T.C. Willson, Southwest Kansas Res. and Ext. Cent., Kansas State Univ., Garden City, KS 67846. Received 18 Apr. 2000. *Corresponding author (sanche22@msu.edu).

Published in Agron. J. 94:391-396 (2002). that root presence increases decomposition rate of soil organic matter (Billes and Bottner, 1981; Fisher and Gosz, 1986b; Cheng and Coleman, 1990). Others reported no change (Cuenca et al., 1983; Harmer and Alexander, $1985)$ or even a reduction in presence of plant roots (Gadgil and Gadgil, 1975; Jenkinson, 1977, Sparling et al., 1982; Fisher and Gosz, 1986a; Staaf, 1988; Faber and Verhoef, 1991).

Reports on the influence of roots on $\mathrm{N}$ mineralization have also been contradictory. A stimulatory effect of plant roots on $\mathrm{N}$ mineralization has been observed in some studies (Bartholomew and Clark, 1950; Molina and Rovira, 1964; Clarholm, 1985a; Berg and Rosswall, 1987; Bottner et al., 1991; Haider et al., 1993). Others have found that the net effect of plant roots is to increase $\mathrm{N}$ immobilization (Huntjens, 1971; Texier and Billes, 1990; Qian et al., 1997). The discrepancy of these results reflects the diversity of soils, plant species, and experimental methods and the complexity of plant-soil interactions and their influence on $\mathrm{C}$ and $\mathrm{N}$ dynamics. Although the addition of N-rich plant residues (Bhattacharyya et al., 1986; Wang and Bakken, 1989) or N fertilizer (Liljeroth et al., 1990; Swinnen et al., 1995) may increase $\mathrm{N}$ mineralization in the presence of plant roots, previous workers have not attempted to identify soil conditions that enhance the stimulatory effect of plant roots on $\mathrm{N}$ mineralization.

In this work, we hypothesize that the presence of living corn roots would increase the $\mathrm{N}$-supplying capacity of a conditioned soil. Soil conditioning, as we define it, is the process of improving the quantity and quality of the mineralizable $\mathrm{N}$ pool. We use practices such as crop rotation, cover crops, and the addition of composted manure to enhance the mineralizable $\mathrm{N}$ pool. Cylinders of PVC were placed in the conditioned soil before planting to confine or exclude roots of corn and wheat. The soil $\mathrm{N}$-supplying capacity was calculated for the bare soil, corn, and wheat treatments $70 \mathrm{~d}$ after planting. Mineralization potentials determined by laboratory incubations were used to quantify changes in the 70-d N (based on $70 \mathrm{~d}$ of incubation) and 150-d C (based on $150 \mathrm{~d}$ of incubation) pools in response to the presence or absence of plant roots.

\section{MATERIALS AND METHODS Site Description}

This research is part of the Living Field Laboratory, a longterm experiment established in 1993 at the Kellogg Biological Station in Hickory Corners, MI. Average precipitation has been $860 \mathrm{~mm} \mathrm{yr}^{-1}$ (1988-1999), and potential evapotranspira- 


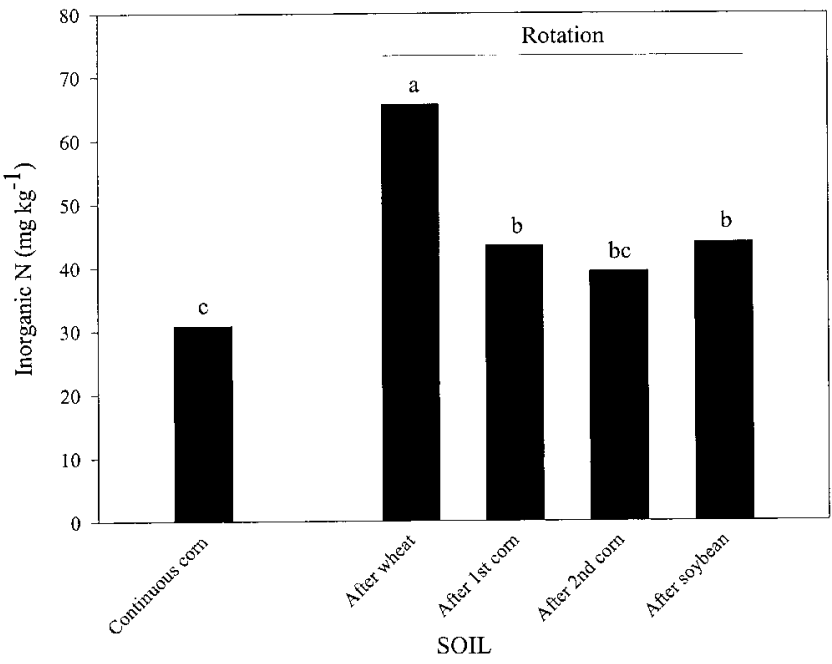

Fig. 1. Net mineralized $\mathbf{N}$ at $70 \mathrm{~d}$ of laboratory incubations for soils from a corn-corn-soybean-wheat rotation and continuous corn at the Living Field Laboratory. Sampling was done in May 1999. Units are based on a $10-\mathrm{cm}$ sample depth. Letters indicate significant differences $(P<0.05)$ in mineralized $N$ after $70 \mathrm{~d}$ of incubation.

tion typically exceeds precipitation from May through September. The soil is a mixture of Kalamazoo (fine-loamy, mixed, mesic Typic Hapludalfs) and Oshtemo (coarse-loamy, mixed, mesic Typic Hapludalfs) sandy loams. The depth of the Ap horizon is 20 to $25 \mathrm{~cm}$, and $\mathrm{pH}$ ranges from 6.3 to 6.8 . The Living Field Laboratory is designed to test various combinations of rotation and cover crops under several agronomic management regimes (Jones, 1998). Its main goal is to test alternative strategies for achieving nutrient-cycling efficiency and reducing chemical input requirements. The plots used for this study received minimal application of pesticides, banded herbicide plus cultivation for weed control, and composted dairy manure as the nutrient source. Approximately $4 \mathrm{Mg}$ $\mathrm{ha}^{-1}$ composted manure $\left(26 \mathrm{~g} \mathrm{~N} \mathrm{~kg}^{-1}\right)$ is added annually to all crops and incorporated with chisel plow 7 to $14 \mathrm{~d}$ before planting. This study includes a field experiment using rootconfining or root-excluding cylinders in the cover-cropped plots of first-year corn in a corn-corn-soybean-wheat rotation. Red clover (Trifolium pratense) is frost-seeded into wheat, crimson clover (T. incarnatum) is interseeded into firstyear corn, and annual ryegrass (Lolium multiflorum) is interseeded into second-year corn as cover crops. The average organic $\mathrm{C}$ content of this soil is $13 \mathrm{~g} \mathrm{~kg}^{-1}$, with a $\mathrm{C} / \mathrm{N}$ ratio of 10. Plots in first-year corn (immediately following wheat + clover) were selected because their soil has a larger 70-d organic $\mathrm{N}$ pool compared with other crops in the rotation or with continuous corn (Fig. 1). Previous work suggests that the 70-d N pool closely represents the portion of organic $\mathrm{N}$ available for mineralization during a growing season (Sanchez et al., 2001). In early May 1998, six PVC cylinders (70 cm long and $30 \mathrm{~cm}$ i.d.) were pressed $60 \mathrm{~cm}$ into the soil with minimal soil disturbance immediately after corn (cv. Pioneer 3751) planting. Two corn plants were allowed to grow in three of the cylinders of each plot, and the corn seeds were removed from the other three rings (bare treatment). Using new firstyear corn plots, the experiment was repeated in 1999 with the addition of three cylinders planted with spring wheat (cv. Russ). Four grams (approx. 100 seeds) of wheat were planted in a radial distribution from the center of the rings.

\section{Field Measurements}

Immediately after cylinder insertion, soil samples were taken at 0 - to 10-, 10- to 25-, 25- to 50-, and 50- to 60-cm depths from each of the four plots to determine initial inorganic $\mathrm{N}$ concentrations. Six extra cores were taken adjacent to each cylinder at 0 - to $10-\mathrm{cm}$ depth and used for laboratory incubations. Soil moisture was controlled in the cylinder, using temporary rain shelters and periodic addition of water, to prevent extreme wetting-drying events and to minimize $\mathrm{NO}_{3}$ leaching and denitrification. We also assumed that controlling the soil moisture would concentrate root growth in the Ap horizon. Soil moisture was determined weekly using time domain reflectometry (Tektronix 1502B). The amount of water to be added was calculated by subtracting the actual soil moisture from the estimated water-holding capacity (Paul et al., 1999) for the $0-$ to $10-\mathrm{cm}$ depth. The calculated amount of water to be added was divided in half, and each part was applied at two different days of the week. Soil moisture was adjusted weekly as needed. Removable plastic shelters were used as needed to exclude rain from the cylinders. Every $14 \mathrm{~d}$, three soil cores $(1.9 \mathrm{~cm}$ diam.) were taken at $0-$ to $10-\mathrm{cm}$ depth from each cylinder. After each sampling, the open holes were plugged using small pieces of PVC pipes ( $15 \mathrm{~cm}$ long). The objective of this sampling was to monitor changes in inorganic $\mathrm{N}$ throughout the experimental period and to confirm soil moisture gravimetrically.

After $70 \mathrm{~d}$, final soil samples were taken at 0 - to $10-\mathrm{cm}$ depth for laboratory incubations, and each cylinder and its intact soil core were removed using a front-end loader. The PVC pipe was separated from the soil core by sawing longitudinally and splitting the pipe, exposing the intact core. Soil samples at 0- to 10-, 10- to 25-, 25- to 50-, and 50- to 60$\mathrm{cm}$ depth were taken from the cores to determine the final inorganic $\mathrm{N}$ concentrations in the confined soil profile ( 0 - to 60 -cm depth). Deep soil samples were also taken from beneath the tubes (60- to $70-\mathrm{cm}$ depth) to determine $\mathrm{N}$ movement below the confined profile. Bulk densities were determined for the 0 - to 10-, 10- to 25-, and 25- to 60-cm depths and used to calculate area-based values of soil inorganic N. The bulk densities of bare soils averaged $1.4 \mathrm{~g} \mathrm{~cm}^{-3}$ in both 0 - to $10-$ and 10 - to $25-\mathrm{cm}$ depths vs. the $1.3 \mathrm{~g} \mathrm{~cm}^{-3}$ found for both corn and wheat soils at those depths. No differences were found among the three soils at 25- to $60-\mathrm{cm}$ depth $\left(1.6 \mathrm{~g} \mathrm{~cm}^{-3}\right)$. Corn and wheat biomass were separated from the soil cores and analyzed for total C and N using a Carlo Erba N A 1500 Series 2 N/C/S analyzer (CE Instruments, Milan, Italy).

\section{Laboratory Measurements}

Inorganic $\mathrm{N}\left(\mathrm{NO}_{3}-\mathrm{N}+\mathrm{NH}_{4}-\mathrm{N}\right)$ concentrations were determined using the extraction technique described by Keeney and Nelson (1982) and a Lachat automated colorimetric analyzer (Lachat Instruments, Milwaukee, WI). For clarity, we will use the terms at planting to describe the soil at Day 0 and final to describe the soil at termination $70 \mathrm{~d}$ after planting. During the preparation of final soils, most remaining roots were removed using a 6-mm sieve. Wheat roots were difficult to separate due to their small size and senescence at the time of sampling. Soil samples from the 0 - to $10-\mathrm{cm}$ depth of each plot were composited by sampling date and treatment and incubated to determine the size of the 70-d N and 150-d C pools in the laboratory. Three (20-g dry weight equivalent) aliquots of each sample were weighed into $100-\mathrm{mL}$ plastic specimen cups and brought to $50 \%$ of water-holding capacity. The specimen cups were stored in plastic storage containers that had a thin layer of water on the bottom to maintain humidity. These containers were then placed in a controlledtemperature room at $25^{\circ} \mathrm{C}$ for 30 and $70 \mathrm{~d}$. At the end of each incubation interval, the corresponding samples were removed and frozen temporarily to stop microbial activity. Inorganic $\mathrm{N}$ was determined using the previously described method. Net 
$\mathrm{N}$ mineralization potential was calculated as the difference between inorganic $\mathrm{N}$ content at the end of the incubation period and that at Day 0. Separate laboratory incubations were used to determine cumulative $\mathrm{C}$ mineralization at 20 , $30,50,70,100$, and $150 \mathrm{~d}$ of incubation. The cumulative mineralization after $150 \mathrm{~d}$ of incubation (150-d C pool) closely represents the active $\mathrm{C}$ pool (Paul et al., 2000). Changes in the 150-d C pool may explain the contribution of rhizodeposition to the active pool.

The inorganic $\mathrm{N}$-supplying capacity of soil was calculated using an $\mathrm{N}$ balance approach:

$$
N_{\mathrm{SC}}=N_{\text {harvested }}+\Delta N_{\text {inorganic (soil) }}
$$

where $N_{\mathrm{SC}}$ is the cumulative inorganic $\mathrm{N}$ supplied by soil during the $70 \mathrm{~d}$ in the field, $N_{\text {harvested }}$ is the harvested shoot and root biomass $\mathrm{N}, \Delta N_{\text {inorganic }}$ is the $\mathrm{N}$ difference between initial and final content of soil inorganic $\mathrm{N}$ measured at 0 - to $60-\mathrm{cm}$ depth. This simplified equation assumes that deep $\mathrm{N}$ leaching was prevented and gaseous $\mathrm{N}$ loss minimized. One can argue against our assumption concerning the lack of gaseous $\mathrm{N}$ loss because no measurement was attempted. Accurate data for denitrification and volatilization are rarely available for upland farming systems (Robertson, 1997). But in a different location within Southwest Michigan, a short-term field experiment using ${ }^{15} \mathrm{~N}$ on a poorly drained soil showed that denitrification amounted to only 1 to $2 \%$ of the immobilization-plusnitrification rates (Christensen et al., 1990). Linn and Doran (1984) reported that in a well-drained soil, the relative activity of anaerobic denitrification is negligible. Also, a recent study in an adjacent field with nearly identical agronomic treatments indicated that $\mathrm{N}$ loss due to denitrification ranged from 1.3 to $0.4 \mathrm{~kg} \mathrm{ha}^{-1} \mathrm{yr}^{-1}$ (Robertson et al., 2000).

\section{Data Analysis}

The same statistical model was applied to the plant biomass $\mathrm{N}$, final inorganic $\mathrm{N}$, and $\mathrm{N}$ supplied by soil data sets. Factors used in the model were field plot, treatment, and replication. The inorganic $\mathrm{N}$ concentration and bulk density in the soil profile data sets used depth as an additional factor. The factors used to analyze the $\mathrm{N}$ and $\mathrm{C}$ mineralization data sets were treatment, date, field replication, and incubation time. In both cases, during the analysis of variance (ANOVA), the data from each incubation interval were treated as repeated measurements of the corresponding experimental unit. The optimal covariance structure was determined using Schwarz's Bayesian Criterion (Littell et al., 1997). The $\mathrm{N}$ and C mineralization data sets were best explained by a compound-symmetry covariance structure, which assumes constant variance and covariance for each diagonal element of the variance-covariance matrix (SAS Inst., 1999). After using ANOVA to identify effects that produce significantly different $\mathrm{N}$ or $\mathrm{C}$ mineralization, the Tukey-Kramer test was used to compare least square means.

\section{RESULTS AND DISCUSSION}

The inorganic $\mathrm{N}$-supplying capacity of soil in the field was increased $>50 \%$ in the presence of corn roots compared with bare soil (Table 1). We suggest that this increase is influenced by the stimulating effect of corn roots on $\mathrm{N}$ mineralization. The effects of roots on soil include uptake of nutrients and water, movement of soil caused by root penetration, and release of rhizodeposits (Priha et al., 1999). The production of rhizodeposits is a direct root control of $\mathrm{N}$ mineralization (Clarholm, 1985b). The plant's release of these organic materials is a significant energy input to the soil microbial community (Bakken, 1990; Texier and Billes, 1990). Whipps (1985) reported that in young corn, 47 to $69 \%$ of the total $\mathrm{C}$ transferred to the roots could be lost in the form of rhizodeposition. Helal and Sauerbeck (1987) estimated that the amount of $\mathrm{C}$ released by corn roots from 7 to $30 \mathrm{~d}$ after planting was equivalent to $>1000$ $\mathrm{kg} \mathrm{ha}^{-1}$ organic matter. This root-derived $\mathrm{C}$ acts as a fuel for a sequence of events that would not occur in the absence of roots (Clarholm, 1985b). First, the presence of these high-energy $\mathrm{C}$ materials increases $\mathrm{N}$ immobilization because soil microorganisms are typically $\mathrm{C}$ limited (Paul and Clark, 1996). Second, N mineralization also increases because of the abundance of low $\mathrm{C} / \mathrm{N}$ ratio substrate in the conditioned soil. The ability of this soil to supply $\mathrm{N}$ in presence of corn roots is enhanced because the expected increased immobilization was counterbalanced by much greater mineralization. It is also possible that some of the additional $\mathrm{N}$ may have come from increased microbial turnover resulting from predation of the enhanced microbial biomass by nematodes and protozoa (Elliott et al., 1979; Clarholm, 1985a, 1985b; Robinson et al., 1989; Kuikman et al., 1990). During these simultaneous processes, corn roots continue releasing organic compounds and removing any surplus of inorganic $\mathrm{N}$, continuously affecting $\mathrm{N}$ dynamics.

According to Martin and Puckridge (1982), wheat plants release considerable amounts of $\mathrm{C}$ into the rhizosphere, but we observed no significant increase in the $\mathrm{N}$ supplied by wheat soil compared with bare soil (Table $1)$. This difference may be related to the amount and

Table 1. Calculation of $\mathbf{N}$ supplied by the planted and bare soils using plant biomass $\mathbf{N}$ and the soil inorganic $\mathbf{N}$ content at 0 - to 60 -cm depth at planting and $70 \mathrm{~d}$ after planting.

\begin{tabular}{|c|c|c|c|c|c|}
\hline \multirow[t]{2}{*}{ Treatments } & $\begin{array}{l}\text { At-planting } \\
\text { inorganic soil N } \\
\text { (A) }\end{array}$ & \multirow[t]{2}{*}{$\begin{array}{c}\text { Shoot N } \\
\text { (B) }\end{array}$} & \multirow[t]{2}{*}{$\begin{array}{c}\text { Root } N \\
\text { (C) }\end{array}$} & \multirow[t]{2}{*}{$\begin{array}{c}\text { Final inorganic } \\
\text { soil N (D) }\end{array}$} & \multirow[t]{2}{*}{$\begin{array}{l}\text { N supplied } \\
\text { by soil }(\mathbf{E})\end{array}$} \\
\hline & & & & & \\
\hline & \multicolumn{4}{|c|}{1998} & \\
\hline Bare & $35.7 \ddagger$ & - & - & 148.0aß & $112.3 b$ \\
\hline Corn & 35.7 & 159.0 & 30.3 & 18.7b & 172.3a \\
\hline \multicolumn{6}{|c|}{1999} \\
\hline Bare & $32.9 \ddagger$ & - & - & 138.4a & $105.5 b$ \\
\hline Corn & 32.9 & 149.1a & $26.9 \mathrm{a}$ & $21.0 c$ & 164.1a \\
\hline Wheat & 32.9 & $82.4 b$ & $10.2 \mathrm{~b}$ & $56.7 \mathrm{~b}$ & $116.4 \mathrm{~b}$ \\
\hline
\end{tabular}

$\dagger \mathbf{E}=\mathbf{B}+\mathbf{C}+\mathbf{D}-\mathbf{A}$.

$\uparrow$ A single bulk sample was used for all treatments at planting.

$\S$ Statistical comparisons are made within years. Least square means within a column followed by the same letter are not significantly different at $P<0.05$. 
Table 2. Inorganic $\mathbf{N}$ concentration in the soil profile at the end of the experiment ( $70 \mathrm{~d}$ after planting).

\begin{tabular}{|c|c|c|c|}
\hline \multirow[b]{2}{*}{ Soil depth } & \multicolumn{3}{|c|}{ Treatments } \\
\hline & Bare & Corn & Wheat \\
\hline \multirow[t]{2}{*}{ cm } & \multicolumn{3}{|c|}{$-\mathrm{mg} \mathrm{kg}^{-1}$} \\
\hline & \multicolumn{2}{|c|}{1998} & \\
\hline $0-25$ & $35.6 \mathrm{a} \dagger$ & $3.5 \mathrm{a}$ & - \\
\hline $25-60$ & $5.9 \mathrm{~b}$ & $1.3 b$ & - \\
\hline \multicolumn{4}{|c|}{1999} \\
\hline 0-10 & $60.6 \mathrm{a}$ & 8.0a & $19.3 \mathbf{a}$ \\
\hline $10-25$ & $19.2 \mathrm{~b}$ & 3.2b & 9.1b \\
\hline $25-50$ & 7.1c & $2.0 \mathrm{c}$ & $4.8 \mathrm{c}$ \\
\hline $50-60$ & 3.7d & $2.1 \mathrm{c}$ & $3.2 \mathrm{c}$ \\
\hline 60-70 & 2.6d & $1.7 \mathrm{c}$ & $2.1 \mathrm{c}$ \\
\hline
\end{tabular}

$\dagger$ Statistical comparisons are made within years. Least square means within a column followed by the same letter are not significantly different at $P<0.05$.

quality of rhizodeposits released into the soil. Merckx et al. (1987) reported that materials released from corn roots were incorporated into the microbial biomass to a higher degree than materials from wheat roots. In addition, corn roots may possess a more vigorous growth habit than wheat, allowing them to expose more organic material to decomposition and compete more efficiently with microbes. Wedin and Tilman (1990) found dramatic divergences of net $\mathrm{N}$ mineralization rates for five different grass species growing in initially identical soils, confirming the potential for strong interactions between plant species and $\mathrm{N}$ cycling. The length of the active growth period may be an additional factor influencing the higher $\mathrm{N}$-supplying capacity found in the soil planted with corn. Corn plants were actively growing at the final days of the experiment, contrasting with the maturing stage observed in wheat plants. This longer period of active growth observed in corn plants may be important because of the additional period for rhizodeposit production and $\mathrm{N}$ uptake. Furthermore, the cropping sequence may have affected wheat performance compared with corn. Planting corn and wheat in a soil planted with wheat the previous year may be beneficial to corn but not necessarily to wheat.

The high $\mathrm{N}$ concentration in the Ap and the small amount in the $\mathrm{C}$ horizon indicate that deep $\mathrm{N}$ leaching was insignificant (Table 2). A more detailed sampling in 1999 shows that the concentration of $\mathrm{N}$ in the 60- to $70-\mathrm{cm}$ depth was $<3 \mathrm{mg} \mathrm{kg}^{-1}$ in all treatments. This low

Table 3. Distribution of root biomass dry weight and $\operatorname{root} \mathbf{N}$ in the soil profile based on recovered roots at the end of the experiment (70 d after planting).

\begin{tabular}{|c|c|c|c|c|}
\hline \multirow[b]{2}{*}{ Soil depth } & \multicolumn{2}{|c|}{ Corn } & \multicolumn{2}{|c|}{ Wheat } \\
\hline & Biomass & $\mathbf{N}$ & Biomass & $\mathbf{N}$ \\
\hline \multirow[t]{2}{*}{ cm } & & - & 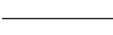 & 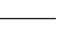 \\
\hline & & 98 & & \\
\hline \multirow[t]{2}{*}{$0-60$} & 3236 & 30.3 & - & - \\
\hline & & 999 & & \\
\hline $0-25$ & 3333a $\dagger$ & 25.2a & $625 a$ & $9.6 \mathrm{a}$ \\
\hline $25-50$ & $205 b$ & $1.4 \mathrm{~b}$ & 13b & $0.5 b$ \\
\hline $50-60$ & 41c & $0.3 \mathrm{c}$ & $2 c$ & $0.1 \mathrm{c}$ \\
\hline
\end{tabular}

$\uparrow$ Statistical comparisons are made within years. Least square means within a column followed by the same letter are not significantly different at $P<0.05$.

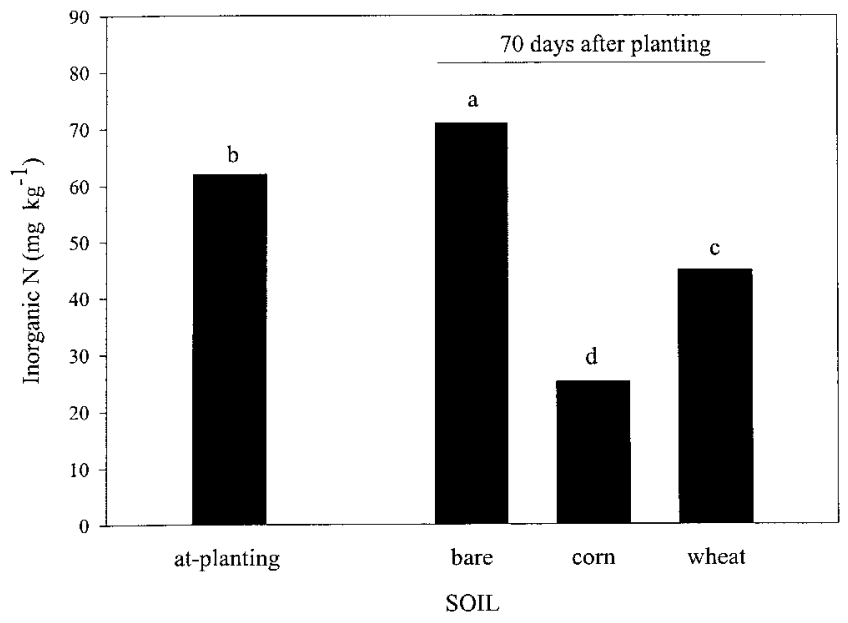

Fig. 2. Net mineralized $\mathbf{N}$ at 70 d of laboratory incubation for atplanting soils and 70-d-after-planting soils in 1999. Units are based on a 10-cm sample depth. Letters indicate significant differences $(P<0.05)$ in mineralized $\mathrm{N}$ after $70 \mathrm{~d}$ of incubation.

$\mathrm{N}$ concentration and the high root concentration in the Ap horizon (Table 3) support the effectiveness of the experimental method in preventing leaching and deep root growth.

The increased net $\mathrm{N}$ mineralization suggested by the increase in the soil $\mathrm{N}$-supplying capacity in presence of corn roots is supported by the laboratory incubations. The 70-d N pool size for the corn treatment was a third of the size of that for the bare soil treatment (Fig. 2). This implies that the additional inorganic N, supplied by the soil in presence of corn roots, was obtained primarily from that particular pool. The significant reduction in the size of the 70-d $\mathrm{N}$ pool for the soil planted with wheat was probably caused by greater $\mathrm{N}$ mineralization during root growth. It is possible that a portion of the mineralized $\mathrm{N}$ became unavailable for wheat plants due to microbial competition. In addition, $\mathrm{N}$ mineralization appears to be significant during wheat senescence at the final days of the experimental period. During this period, wheat uptake is minimal, and the mineralized $\mathrm{N}$ is expected to accumulate. Results from the monitoring sampling (data not shown) indicate that inorganic $\mathrm{N}$ decreased after Day 28 in both corn and wheat soils. In the soil planted with corn, this reduction continued in each sampling date thereafter. In contrast, the soil planted with wheat experienced a substantial increase in inorganic $\mathrm{N}$ after Day 56. The increase in the 70-d $\mathrm{N}$ pool for the bare soil compared with the at-planting soil (Fig. 2) may be due to the transformation of a portion of the less active $\mathrm{N}$ pool into more readily available forms during the May-June period with optimal soil moisture and temperature.

The greater mineralization of soil $\mathrm{N}$ in the presence of growing corn is undoubtedly linked to an increase in the mineralization of soil C. However, the laboratory incubation data indicate that the size of the $150-\mathrm{d} C$ pool was not decreased after corn growth, whereas it was decreased in the wheat and bare soil treatments (Fig. 3). Rhizodeposition was sufficient to compensate for the $\mathrm{C}$ used during $\mathrm{N}$ mineralization in the soil planted 


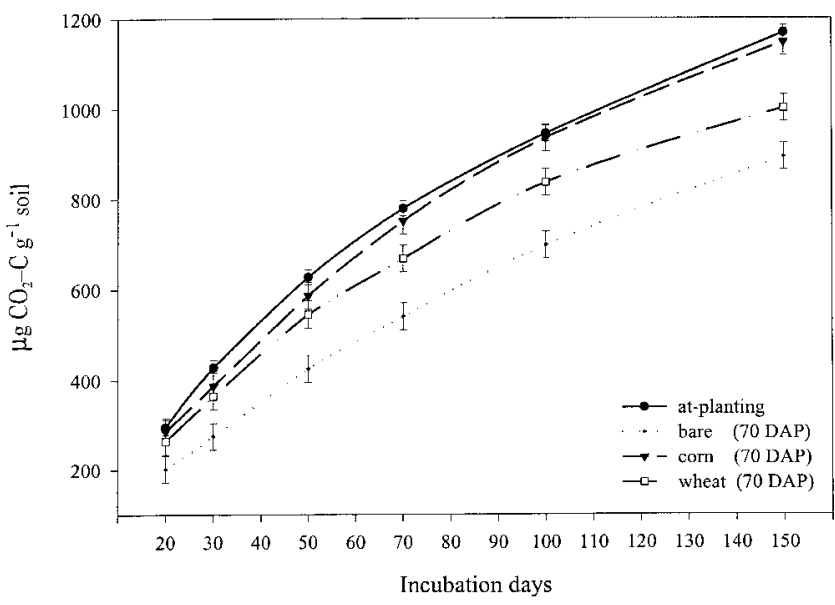

Fig. 3. Net mineralized $\mathrm{C}$ based on $\mathrm{CO}_{2}-\mathrm{C}$ released during laboratory incubations for at-planting and 70-d-after-planting (70 DAP) soils in 1999. Units are based on a 10-cm sample depth. Error bars represent the standard errors of the least square means.

with corn but not in the soil planted with wheat. It is likely that root-derived $\mathrm{C}$ is a relatively more important energy source for microbial activity under corn than under wheat. Our data agree with those of Shields and Paul (1973), Reid and Goss (1982, 1983), and Haider et al. $(1989,1993)$ showing that growing plants tend to maintain soil C levels, whereas bare soil tends to decrease it.

We conclude that in the presence of an enhanced mineralizable $\mathrm{N}$ pool, corn roots increase $\mathrm{N}$ mineralization to a greater extent than do wheat roots. Further studies are needed to classify plant species and cultivars according to their level of stimulation in the presence of varying $\mathrm{N}$ pool sizes.

\section{ACKNOWLEDGMENTS}

Our special thanks to the C.S. Mott Chair of Sustainable Agriculture and Michigan State Agricultural Experiment Station for their financial support that made this study possible.

\section{REFERENCES}

Bakken, L.R. 1990. Microbial growth and immobilization/mineralization of $\mathrm{N}$ in the rhizosphere. Symbiosis 9:37-41.

Barber, D.A., and J.M. Lynch. 1977. Microbial growth in the rhizosphere. Soil Biol. Biochem. 21:773-778.

Bartholomew, W.V., and F.E. Clark. 1950. Nitrogen transformations in soil in relation to the rhizosphere microflora. Trans. Int. Congr. Soil Sci., 4th, 1950 2:112-113.

Bazin, M.J., P. Markham, E.M. Scott, and J.M. Lynch. 1990. Population dynamics and rhizosphere interactions. p. 99-127. In J.M Lynch (ed.) The rhizosphere. John Wiley \& Sons, Chichester, UK.

Berg, P., and T. Rosswall. 1987. Seasonal variations in abundance and activity of nitrifiers in four arable cropping systems. Microbiol. Ecol. 13:75-87.

Bhattacharyya, P., B.K. Dey, S. Nath, and S. Banik. 1986. Organic manures in relation to rhizosphere effect: III. Effect of organic manures on population of ammonifying bacteria and mineralization of nitrogen in rice and succeeding wheat rhizosphere soils. Zentralbl. Mikrobiol. 141:267-277.

Billes, G., and P. Bottner. 1981. Living roots effect on ${ }^{14} \mathrm{C}$ carbon isotope-labelled root litter decomposition. Plant Soil 62:193-208.

Bottner, P., J. Cortez, and Z. Sallih. 1991. Effect of living roots on carbon and nitrogen of the soil microbial biomass. p. 201-210. In Special publication of the British Ecological Society. Vol. 10 Blackwell Sci. Publ., Oxford.
Cheng, W., and D.C. Coleman. 1990. Effect of living roots on soil organic matter decomposition. Soil Biol. Biochem. 22:781-788.

Christensen, S., P. Groffman, A. Mosier, and D.R. Zak. 1990. Rhizosphere denitrification: A minor process but indicator of decomposition activity. FEMS Symp. 56:199-211.

Clarholm, M. 1985a. Interactions of bacteria, protozoa and plants leading to mineralization of soil nitrogen. Soil Biol. Biochem. 17: 181-187.

Clarholm, M. 1985b. Possible roles for roots, bacteria, protozoa, and fungi in supplying nitrogen to plants. p. 355-365. In A.E. Fitter (ed.) Ecological interactions in soil: Plants, microbes and animals. Blackwell Sci. Publ., Boston.

Cuenca, G., J. Aranguren, and R. Herrara. 1983. Root growth and litter decomposition in a coffee plantation under shade trees. Plant Soil 71:477-486.

Curl, E.A., and J.D. Harper. 1990. Fauna-microflora interactions. p. 369-388. In J.M. Lynch (ed.) The rhizosphere. John Wiley \& Sons, Chichester, UK.

Elliott, E.T., D.C. Coleman, and C.V. Cole. 1979. The influence of amoeba on the uptake of nitrogen by plants in gnotobiotic soil. $p$ 221-229. In J.L. Harley and R.S. Russell (ed.) The soil-root interface. Academic Press, London.

Faber, J.H., and H.A. Verhoef. 1991. Functional differences between closely related soil arthropods with respect to decomposition process in the presence or absence of pine tree roots. Soil Biol. Biochem. 23:15-23.

Fisher, F.M., and J.R. Gosz. 1986a. Effect of trenching on soil processes and properties in a New Mexico mixed-conifer forest. Biol. Fertil. Soils 2:35-42.

Fisher, F.M., and J.R. Gosz. 1986b. Effect of plants on net mineralization of nitrogen in forest soil microcosms. Biol. Fertil. Soils. 2:43-50.

Foster, R.C. 1988. Microenvironments of soil microorganisms. Biol Fertil. Soils 6:189-203.

Gadgil, R.L., and P.D. Gadgil. 1975. Suppression of litter decomposition by mycorrhizal roots of Pinus radiata. N.Z. J. For. Sci. 5:33-41.

Haider, K., O. Heinemeyer, and A. Mosier. 1989. Effects of growing plants on humus and plant residue decomposition in soil: Uptake of decomposition products by plants. Sci. Total Environ. 81/82: 661-670.

Haider, K., A. Mosier, and O. Heinemeyer. 1993. Impact of growing corn plants on N-utilization from fertilizer, crop residues and on organic N- and C-mineralization. Soil Sci. (Trends Agric. Sci.) 1: 183-191

Harmer, R., and J.J. Alexander. 1985. Effect of root exclusion on nitrogen transformations and decomposition processes in spruce humus. p. 267-278. In A.H. Fitter et al. (ed.) Ecological interactions in soil. Blackwell Sci., Oxford, UK.

Helal, H.M., and D. Sauerbeck. 1987. Direct and indirect influences of plant root on organic matter and phosphorus turnover in soil. p. 49-58. In J.H. Couley (ed.) Soil organic matter dynamics and soil productivity. INTECOL Bull. 15. Int. Assoc. for Ecol., Athens, GA

Huntjens, J.L.M. 1971. The influence of living plants on mineralization of nitrogen. Plant Soil 35:77-94.

Jenkinson, D.S. 1977. Studies on the decomposition of plant material in soil: V. The effect of plant cover and soil type on the loss of ${ }^{14} \mathrm{C}$-labelled ryegrass decomposing under field conditions. J. Soil Sci. 28:424-434.

Jones, M.E., R.R. Harwood, N.C. Dehne, J. Smeenk, and E. Parker. 1998. Enhancing soil nitrogen mineralization and corn yield with overseeded cover crops. J. Soil Water Conserv. 53:245-249.

Keeney, D.R., and D.W. Nelson. 1982. Nitrogen: Inorganic forms. p. 643-698. In A.L. Page et al. (ed.) Methods of soil analysis. Part 2. 2nd ed. Agron. Monogr. 9. ASA, Madison, WI.

Kuikman, P.J., A.G. Jansen, J.A. van Veen, and A.J.B. Zehnder 1990. Protozoan predation and the turnover of soil organic carbon and nitrogen in the presence of plants. Biol. Fertil. Soils 10:22-28.

Liljeroth, E., J.A. van Veen, and H.J. Miller. 1990. Assimilate translocation to the rhizosphere of two wheat lines and subsequent utilization by rhizosphere microorganism at two soil nitrogen concentrations. Soil Biol. Biochem. 22:1015-1021.

Linn, D.M., and J.W. Doran. 1984. Effect of water-filled pore space on carbon dioxide and nitrous oxide production in tilled and nontilled soils. Soil Sci. Soc. Am. J. 48:1267-1272.

Littell, R.C., G.A. Milliken, W.W. Stroup, and R.D. Wolfinger. 1997. SAS system for mixed models. SAS Inst., Cary, NC. 
Martin, J.K., and D.W. Puckridge. 1982. Carbon flow through the rhizosphere of wheat crops in South Australia. p. 77-81. In I.E Galbally and J.R. Freney (ed.) The cycling of carbon, nitrogen, sulfur, and phosphorus in terrestrial and aquatic ecosystems. Australian Acad. of Sci., Canberra.

Meisinger J.J., V.A. Bandel, G. Stanford, and J.O. Legg. 1985. Nitrogen utilization of corn under minimal tillage and moldboard plow tillage: I. Four-year results using labeled $\mathrm{N}$ fertilizer on an Atlantic Coastal Plain soil. Agron. J. 77:602-611.

Merckx, R., A. Dijkstra, A. den Hartog, and J.A. van Veen. 1987. Production of root-derived material and associated microbial growth in soil at different nutrient levels. Biol. Fertil. Soils 5:126132.

Molina, J.A.E., and A.D. Rovira. 1964. The influence of plant roots on autotrophic nitrifying bacteria. Can. J. Microbiol. 10:249-257.

Newman, E.I. 1985. The rhizosphere: Carbon sources and microbial populations. p. 107-121. In A.H. Fitter (ed.) Ecological interactions in soil. Blackwell Sci. Publ., Oxford.

Paul, E.A., and F.E. Clark. 1996. Soil microbiology and biochemistry. Academic Press, San Diego, CA.

Paul, E.A., D. Harris, M.J. Klug, and R.W. Ruess. 1999. The determination of microbial biomass. In G.P. Robertson et al. (ed.) Standard soil methods for long-term ecological research. Oxford Univ. Press, New York.

Paul, E.A., S.J. Morris, and S. Bohm. 2000. The determination of pool sizes and turnover rates: Biophysical fractionation and tracers. In R. Lal et al. (ed.) Assessment methods for soil C pools. CRC Press, Boca Raton, FL.

Priha, O., T. Lehto, and A. Smolander. 1999. Mycorrhizas and C and $\mathrm{N}$ transformations in the rhizosphere of Pinus sylvestris, Pices abies and Betula pendula seedlings. Plant Soil 206:191-204.

Qian, J.H., J.W. Doran, and D.T. Walters. 1997. Maize plant contributions to root zone available carbon and microbial transformation of nitrogen. Soil Biol. Biochem. 29:1451-1462.

Reid, J.B., and M.J. Goss. 1982. Suppression of decomposition of ${ }^{14} \mathrm{C}-$ labelled plant roots in the presence of living roots of maize and perennial ryegrass. J. Soil Sci. 33:387-395.

Reid, J.B., and M.J. Goss. 1983. Growing crops and transformations of ${ }^{14} \mathrm{C}$-labelled soil organic matter. Soil Biol. Biochem. 15:687-691.

Robertson, G.P. 1997. Nitrogen use efficiency in row-crop agriculture:
Crop nitrogen use and soil nitrogen loss. p. 347-365. In L.E. Jackson (ed.) Ecology in agriculture. Academic Press, San Diego, CA.

Robertson, G.P., E.A. Paul, and R.R. Harwood. 2000. Greenhouse gases in intensive agriculture: Contributions of individual gases to the radiative forcing of the atmosphere. Science 289:1922-1925

Robinson, D., B. Griffiths, K. Ritz, and R. Wheatley. 1989. Rootinduced nitrogen mineralization: A theoretical analysis. Plant Soil 117:185-193.

Sanchez, C.A., and A.M. Blackmer. 1988. Recovery of anhydrous ammonia-derived nitrogen- 15 during three years of corn production in Iowa. Agron. J. 80:102-108.

Sanchez, J.E., T.C. Willson, K. Kizilkaya, E. Parker, and R.R. Harwood. 2001. Enhancing the mineralizable nitrogen pool through substrate diversity in long-term cropping systems. Soil Sci. Soc. Am. J. 65:1442-1447.

SAS Institute. 1999. The SAS system for Windows. Release 8.0. SAS Inst., Cary, NC.

Shields, J.A., and E.A. Paul. 1973. Decomposition of ${ }^{14} \mathrm{C}$-labeled soil organic matter. Can. J. Soil Sci. 53:297-306.

Sparling, G.P., M.V. Cheshire, and C.M. Mundie. 1982. Effect of barley plants on the decomposition of ${ }^{14} \mathrm{C}$-labelled soil organic matter. J. Soil Sci. 33:89-100.

Staaf, H. 1988. Litter decomposition in beech forest: Effect of excluding tree roots. Biol. Fertil. Soils 6:302-305.

Swinnen, J., J.A. van Veen, and R. Merckx. 1995. Root decay and turnover of rhizodeposits in field-grown winter wheat and spring barley estimated by ${ }^{14} \mathrm{C}$ pulse-labeling. Soil Biol. Biochem. 27:211217.

Texier, M., and G. Billes. 1990. The role of the rhizosphere on C and $\mathrm{N}$ cycles in a plant-soil system. Symbiosis 9:117-123.

Wang, J., and L.R. Bakken. 1989. Nitrogen mineralization in rhizosphere and non-rhizosphere soil: Effect of the spatial distribution of N-rich and N-poor plant residues. p. 81-97. In J.A. Hansen and K. Henriksen (ed.) Nitrogen in organic wastes applied to soils. Academic Press, San Diego, CA.

Wedin, D.A., and D. Tilman. 1990. Species effects on nitrogen cycling: A test with perennial grasses. Oecologia. 84:433-441.

Whipps, J.M. 1985. Effect of $\mathrm{CO}_{2}$ concentration on growth, carbon distribution and loss of carbon from the roots of maize. J. Exp. Bot. 36:644-651. 